\title{
Identification of Lactic Acid Bacteria from Papuan Red Fruit (Pandanus conoideus Lam.) with Potential as Probiotics and Antibacterials
}

\author{
Charis Amarantini $^{1 *}$, Vinsa Cantya Prakasita ${ }^{1}$, Viona Ch Salakory ${ }^{2}$
}

${ }^{1}$ Department Biology, Faculty of Biotechnology, Duta Wacana Christian University, Jl. Dr. Wahidin Sudirohusodo No.5-25, Kotabaru, Gondokusuman, Yogyakarta, Daerah Istimewa Yogyakarta 55224, Indonesia

${ }^{2}$ Undergraduate Program, Faculty of Biotechnology, Duta Wacana Christian University, Jl. Dr. Wahidin Sudirohusodo No.5-25, Kotabaru, Gondokusuman, Yogyakarta, Daerah Istimewa Yogyakarta 55224, Indonesia

DOI: $10.36347 /$ sajb.2020.v08i09.006 $\quad$ | Received: 06.09.2020| Accepted: 14.09.2020| Published: 30.09 .2020

*Corresponding author: Charis Amarantini

Abstract Original Research Article

Lactic acid bacteria (LAB) are mostly explored for probiotic activities. These organisms improve the organoleptic characteristics of food, inhibit microbial activities, and consequently prevent possible diseases. The aim of this study, therefore, is to investigate organisms with possible inhibitory action against pathogenic bacteria. Besides, Papuan red fruits obtained from Sorong (West Papuan) and Timika (Papuan) were estimated to contain LAB, hence samples were selected and isolated using de Man Rogosa Sharpe selective medium equipped with $1 \% \mathrm{CaCO}_{3}$. The organisms were then analyzed based on acid sensitivity $(\mathrm{pH} 2,3$, and 4$)$ and bile tolerance $(0.3 \% ; 0.5 \%$ and $1 \%)$. The antibacterial activity was evaluated using well diffusion method on the Muller Hilton Agar medium against pathogenic bacteria Staphylococcus aureus ATCC 25923, Salmonella typhi BPE 122.4 CCA, and Salmonella typhi NCTC 786. The identity of LAB isolates was confirmed based on the API 50CHL test, and a total of 25 isolates were successfully selected. These were characterized based on the cellular properties of rod-shaped, Gram-positive, homofermentative, non-motile, catalase-negative, as well as the capacity to grow at $10^{\circ} \mathrm{C}$ and $45^{\circ} \mathrm{C}$. Furthermore, five of the isolates (strains S1B1, S2B1, S1T2, S2T4, and S1T1) were identified as Lactobacillus plantarum, with the ability to survive at $\mathrm{pH} 2$ and in $1 \%$ bile salts. The antibacterial activity of the S2T4 strain was strong against S. aureus ATCC 25923, S. typhi BPE 122.4 CCA, and S. typhi NCTC 786. Besides, LAB S2B1 significantly restrained the growth of Salmonella typhi BPE 122.4 CCA, while LAB S1T1 inhibited S. aureus ATCC 25923. Therefore, it is possible to further explore Lactobacillus plantarum strains S2T4, S2B1, and S1T1 for the inherent health and nutritional values.

Keywords: Lactic acid bacteria, Pandanus conoideus Lam., Probiotics, Antibacterial, Lactobacillus plantarum. Copyright @ 2020: This is an open-access article distributed under the terms of the Creative Commons Attribution license which permits unrestricted use, distribution, and reproduction in any medium for non-commercial use (NonCommercial, or CC-BY-NC) provided the original author and source are credited

\section{INTRODUCTION}

Lactic acid bacteria (LAB) are known to play a crucial role in the preservation and fermented foods. These organisms have been applied as natural microflora or as starter culture introduced under controlled conditions [1]. According to Gutiérrez-Cortés et al. [2], LAB metabolites can improve the organoleptic characteristics of fermented food and inhibit the growth of microorganisms responsible for food spoilage. These bacteria are classified as probiotics, considering the positive impact on human health. Meanwhile, there are numerous advantages derived from the consumption, including to increase immunity, suppress pathogenic bacteria, balance intestinal microbiota, and reduce serum cholesterol [3].

According to Allen et al. [3], LAB is used as a probiotic, particularly due to the inherent resistance against acids and bile. This microorganism can produce antibacterial substances required to suppress pathogenic enteric bacteria growth. Besides, the antifungal property produced is known to extend the shelf life of food, hence the potential for application as a natural preservative in various edible products [4].

Several studies have successfully obtained LAB strains from various soured beverage ingredients, including yogurt and traditional fermented foods, specifically tape, growol and gatot [5]. The microorganism yield is naturally dominant in dairy products, whole grains, meat, fish, fruit, juices drinks, pickled vegetables, and sourdough batter. Meanwhile, numerous reports are indicating the minute quantities present in all plant materials, while abundant amounts have been observed in decaying varieties, especially rotting fruits. The species isolated from various plant sources include Lactobacillus plantarum, L. brevis, L. 
coryniformis, L. casei, L. curvatus, L. fermentum [6, 7]. Furthermore, LAB is obtainable from a wide range of vegetable-based fermented products, encompassing flowers, and fruits [8].

The red fruit (Pandanus conoideus Lam.) is an endemic plant in Papua province, Indonesia and New Guinea [9]. Moreover, the inulin content in pedicel extract, a byproduct of red fruit oil production, is known to increase Lactobacillus casei growth. This also creates a more acidic environment and inhibits the development of enteric bacteria [10]. Meanwhile, LAB obtained from endemic plants and dominant in red fruit have good explorative potentials, especially as biocontrol and probiotic agents [8]. The aim of this research, therefore, is to isolation and identification LAB with probiotic and antibacterial characteristics, from Papuan red fruit (Pandanus conoideus Lam.).

\section{MATERIAL AND METHODS \\ Red Fruit Samples}

Samples of red fruit were obtained from Timika (Papua Province) and Sorong (West Papua Province) was sliced into 3 parts. Therefore, the pulp sections were collected from each piece and reserved for 72 hours, to ensure the spontaneous fermentation required for lactic acid bacteria growth.

\section{Isolation and selection of Lactic Acid Bacteria}

A total of $25 \mathrm{~g}$ of red fruit were inoculated into 225 mL de Mann Rogosa Sharpe (MRS, Oxoid) liquid medium and incubated at $37^{\circ} \mathrm{C}$ for 48 hours. Furthermore, step dilution was carried out by inoculation through the pour plate method into the MRS agar medium completed with $1 \% \mathrm{CaCO}_{3}$ (Merck), before incubating at $37^{\circ} \mathrm{C}$ for 48 hours. The bacteria were then selected based on phenotypic properties through Gram stain, catalase, gas production, motility test, and survival at $10^{\circ} \mathrm{C}$ or $45^{\circ} \mathrm{C}[11,12]$.

\section{Probiotic Selection}

LAB potential as a probiotic candidate was selected through a tolerance test for acidic $\mathrm{pH}$ and bile salts, along with antibacterial assessment.

\section{Acid pH tolerance test}

The LAB isolates were grown in $5 \mathrm{ml}$ of liquid MRS medium for 48 hours, and the cells were harvested by centrifugation at $13,500 \mathrm{rpm}$ for 15 minutes. Furthermore, the cell pellets were washed twice with Phosphate Buffer Saline (PBS, Merck) and dissolved in $100 \mu 1$ of PBS solution. These globules were then inoculated into a liquid MRS medium adjusted to $\mathrm{pH} 2$, 3 , and 4 for 4 hours at $37^{\circ} \mathrm{C}$. Subsequently, the respective culture growth results were determined by growing on MRS agar using the streak plate method. This was followed by incubation at $37^{\circ} \mathrm{C}$ for 24 to 48 hours [13].

\section{Bile salts tolerance test}

Approximately, $1 \mathrm{ml}$ of LAB culture aged 48 hours was inoculated into $5 \mathrm{ml}$ liquid MRS medium containing bile salts (Oxoid) with concentrations of $0.3 \%, 0.5 \%$, and $1 \%$. Furthermore, growth tests were carried out after 4 hours incubation at $37^{\circ} \mathrm{C}$ by inoculating on the MRS agar medium using streak plate method and incubated at $37^{\circ} \mathrm{C}$ for 24 to 48 hours [13].

\section{Potential Test as Antibacterial Solution preparation of Cell-Free Culture Supernatant (CFCS)}

The LAB cultures were obtained by ose aseptically, inoculated in $5 \mathrm{~mL}$ of liquid MRS medium, and incubated at $37^{\circ} \mathrm{C}$ for 18 hours. Besides, the CFCS solution was harvested by centrifugation at $13,500 \mathrm{rpm}$ for 15 minutes. Meanwhile, the supernatant was neutralized at $\mathrm{pH} 6.5$ with $1 \mathrm{~N} \mathrm{NaOH}$ solution and refrigerated before being used for antibacterial assessment [14].

\section{Pathogenic bacteria strain preparation}

The pathogenic bacteria used were Gram-positive, specifically Staphylococcus aureus ATCC 25923. However, Salmonella typhi 122.4 CCA [15] and Salmonella typhi NCTC 786 obtained from PT. Biofarma were equally used. These bacterial cultures were obtained by ose aseptically and inoculated into liquid BHI medium at $37^{\circ} \mathrm{C}$ for 18 hours before applying antibacterial analysis.

\section{Antibacterial activity test}

The potential of LAB as an antibacterial was tested using the CFCS solution based on the well-diffusion agar method [14, 16, 17]. Besides, an 8 $\mathrm{mm}$ well was created in Mueller Hinton agar (MHA, Oxoid) medium, then indicator bacteria swab was performed using sterile cotton on the surface. Therefore, each well was filled with $100 \mu \mathrm{l}$ of CFCS solution and allowed to cool, to permit a more rapid diffusion, before the petri dishes were incubated at $37^{\circ} \mathrm{C}$ for 24 hours. Furthermore, antibacterial activities were determined based on the assessment of clear zone $(\mathrm{mm})$ formed around the well, where bacterial growth was reduced to a well diameter $(8 \mathrm{~mm})$ [18, 19].

\section{Identification of Lactic Acid Bacteria}

The LAB isolates with probiotic and antibacterial potential were identified using $50 \mathrm{CHL}$ Analytical Profile Index (API) (BioMerieux) and grown in MRS agar medium for 48 hours. These cultures were obtained aseptically and inoculated into ampoules containing $50 \mathrm{CHL}$ API medium, with turbidity equalized to the 2 McFarland. Furthermore, the specimen was inoculated into a microtube strip at an API 50CHL kit and incubated for 48 hours according to a predetermined procedure [20]. Also, the respective identity was determined using an API web software and 
based on the fermentation profile of 49 types of carbohydrates contained in the kit.

\section{RESULTS AND DISCUSSION}

\section{Isolation and Selection of Lactic Acid Bacteria from Red Fruit}

Figure 1 depicts the growth of LAB colonies in the MRS agar medium equipped with $\mathrm{CaCO}_{3}$. This is characterized by the formation of a clear zone, due to a reaction between the chemical and lactic acid compounds where dissolved calcium lactate (Ca-lactate) is produced [21]. The colonies with clear zones are then selected through phenotypic tests to determine the bacteria main character. Table 1 illustrates 25 LAB isolates obtained in the form of rods, Gram-positive, homofermentative, non-motile, and catalase-negative cells, grown at $10^{\circ} \mathrm{C}$ and $45^{\circ} \mathrm{C}$, according to the digestive tract temperature range. These are the predominant bacteria traits [22], used in the selection of potential probiotics.

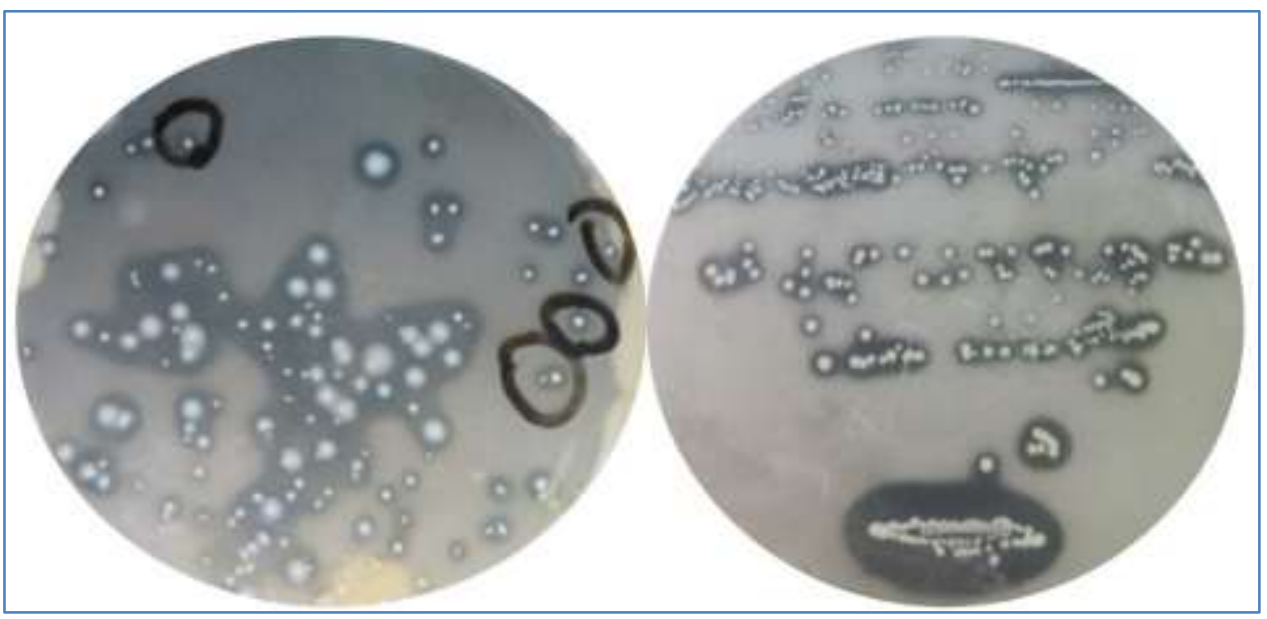

Fig-1: The isolation results of lactic acid bacteria from Papua red fruit (Pandanus conoideus Lam.) on the MRS agar medium equipped with $\mathrm{CACO}_{3}$

According to Table 1, the 25 selected LAB isolates were grown in homofermentative conditions at $10^{\circ} \mathrm{C}$ and $45^{\circ} \mathrm{C}$. This means there was no gas production during the growth phase. These results make it possible to determine the potential to isolate technology in food industry applications [2]. Based on the tolerance test, 24 lived on $0.3 \%$ while 18 out of the total survived with $1 \%$ bile salts. Moreover, 8 lived in acidic environments of up to $\mathrm{pH}$ 2. The probiotic microbe requires strength to survive against various extreme conditions in the human digestive tract, including acidic $\mathrm{pH}$ and bile salts [23]. These characteristics are important for the organism to reach the digestive tract alive, adhere to the mucosal layer and other components of the extracellular matrix. Also, the formation of a fast-microbial community triggers a reduction in $\mathrm{pH}$ and competition for adhesion with pathogenic bacteria, therefore preventing colonization [13]. The ability to fight stomach acid is considered as the main condition during screening because these bacteria pass through the stomach before digestion. Moreover, gastric acid in the human body has a $\mathrm{pH}$ of 3 with a digestion time between 1-3 hours. Therefore, the tolerant LAB is assumed to be a potential probiotic candidate [24].

Table-1: Characteristics of LAB isolates from Papuan red fruit (Pandanus conoideus Lam.), a potential probiotic candidate

\begin{tabular}{|c|c|c|c|c|c|c|c|c|c|c|}
\hline \multirow[t]{2}{*}{ No } & \multirow[t]{2}{*}{ Isolate } & \multicolumn{3}{|c|}{ Acid pH tolerance test } & \multicolumn{3}{|c|}{ Bile salts tolerance test (\%) } & \multicolumn{2}{|c|}{ Temperature test $\left({ }^{0} \mathrm{C}\right)$} & \multirow[t]{2}{*}{ Gas Production } \\
\hline & & 2 & 3 & 4 & 0,3 & 0,5 & 1 & 10 & 45 & \\
\hline 1 & S1A1 & - & - & + & + & - & - & + & + & Homofermentative \\
\hline 2 & S1A2 & - & - & - & + & - & - & + & + & Homofermentative \\
\hline 3 & S1A3 & - & + & + & + & + & + & + & + & Homofermentative \\
\hline 4 & S1A4 & - & - & - & + & + & + & + & + & Homofermentative \\
\hline 5 & S1T1 & - & + & + & + & + & + & + & + & Homofermentative \\
\hline 6 & S1T2 & + & + & + & + & + & + & + & + & Homofermentative \\
\hline 7 & S1T3 & + & + & + & + & + & + & + & + & Homofermentative \\
\hline 8 & S1T4 & + & + & + & + & + & + & + & + & Homofermentative \\
\hline 9 & S1B1 & + & + & + & + & + & + & + & + & Homofermentative \\
\hline 10 & S1B2 & - & + & + & + & + & + & + & + & Homofermentative \\
\hline 11 & S1B3 & - & - & + & + & + & + & + & + & Homofermentative \\
\hline 12 & S2A1 & - & - & + & - & - & - & + & + & Homofermentative \\
\hline
\end{tabular}


Charis Amarantini et al., Sch Acad J Biosci, September, 2020; 8(9): 301-308

\begin{tabular}{|l|l|c|c|c|c|c|c|c|c|c|}
\hline 13 & S2A2 & - & - & - & + & + & - & + & + & Homofermentative \\
\hline 14 & S2A3 & - & - & - & + & + & + & + & + & Homofermentative \\
\hline 15 & S2A4 & - & + & + & + & + & - & + & + & Homofermentative \\
\hline 16 & S2T1 & - & - & + & + & + & + & + & + & Homofermentative \\
\hline 17 & S2T2 & + & + & + & + & + & + & + & + & Homofermentative \\
\hline 18 & S2T3 & + & + & + & + & + & + & + & + & Homofermentative \\
\hline 19 & S2T4 & + & + & + & + & + & + & + & + & Homofermentative \\
\hline 20 & S2T5 & - & - & - & + & + & - & + & + & Homofermentative \\
\hline 21 & S2T6 & - & - & - & + & + & - & + & + & Homofermentative \\
\hline 22 & S2B1 & + & + & + & + & + & + & + & + & Homofermentative \\
\hline 23 & S2B2 & - & - & - & + & + & + & + & + & Homofermentative \\
\hline 24 & S2B3 & - & - & - & + & + & + & + & + & Homofermentative \\
\hline 25 & S2B4 & - & - & - & + & + & + & + & + & Homofermentative \\
\hline
\end{tabular}

Description: (+) LAB growth; (-) LAB not growth

Determination of Lactic Acid Antibacterial Activity based on agar well diffusion method

The Agar well diffusion method was used to determine the antibacterial activity produced by LAB isolates as potential probiotic candidates. This ability was tested against three pathogenic organisms, including S. aureus ATCC 25923 representing Gram-positive bacteria, while S. typhi BPE 122.4 CCA and Salmonella typhi NCTC 786 as Gram-negative. The results in table 2 showed a different inhibition spectrum for each bacterium. According to a report by [18], the activity against the pathogenic bacteria is grouped into 3 categories, including weak $(0-3 \mathrm{~mm})$, moderate $(3-6 \mathrm{~mm})$, and strong $(>6 \mathrm{~mm})$ activity.

Table-2: Antibacterial activity of LAB isolates from Papua red fruit (Pandanus conoideus Lam.) against pathogenic bacteria based on agar well diffusion method.

\begin{tabular}{|c|c|c|c|}
\hline \multirow{2}{*}{ Isolate } & \multicolumn{3}{|c|}{ Inhibition zone (mm) against indicator bacteria } \\
\cline { 2 - 4 } & $\begin{array}{c}\text { Salmonella typhi } \\
\text { BPE 122.4 CCA }\end{array}$ & $\begin{array}{c}\text { Salmonella typhi } \\
\text { NCTC 786 }\end{array}$ & $\begin{array}{c}\text { Staphylococcus aureus } \\
\text { ATCC 25923 }\end{array}$ \\
\hline S1A1 & $2.00 \pm 0.00$ & $2.33 \pm 0.58$ & $2.33 \pm 0.58$ \\
\hline S1A2 & $2.33 \pm 0.57$ & $3.67 \pm 0.58$ & $2.00 \pm 0.00$ \\
\hline S1A3 & $2.33 \pm 0.58$ & $1.33 \pm 0.58$ & $3.33 \pm 0.58$ \\
\hline S1A4 & $2.00 \pm 1.00$ & $4.00 \pm 1.00$ & $2.67 \pm 0.57$ \\
\hline S1T1 & $2.33 \pm 0.57$ & $5.53 \pm 0.57$ & $6.67 \pm 0.57 *$ \\
\hline S1T2 & $3.00 \pm 0.00$ & $1.67 \pm 0.57$ & $2.33 \pm 0.57$ \\
\hline S1T3 & $2.33 \pm 0.58$ & $1.33 \pm 0.57$ & $1.67 \pm 0.57$ \\
\hline S1T4 & $2.67 \pm 0.58$ & $1.00 \pm 0.00$ & $3.33 \pm 0.57$ \\
\hline S1B1 & $3.00 \pm 0.00$ & $2.67 \pm 0.57$ & $2.33 \pm 0.57$ \\
\hline S1B2 & $1.00 \pm 0.00$ & $1.67 \pm 0.57$ & $2.67 \pm 0.57$ \\
\hline S1B3 & $2.00 \pm 1.00$ & $3.00 \pm 1.00$ & $2.00 \pm 1.00$ \\
\hline S2A1 & $2.00 \pm 0.00$ & $2.33 \pm 0.57$ & $1.33 \pm 0.57$ \\
\hline S2A2 & $3.00 \pm 1.00$ & $2.67 \pm 0.57$ & $1.00 \pm 0.00$ \\
\hline S2A3 & $2.33 \pm 0.57$ & $2.67 \pm 0.57$ & $2.33 \pm 0.57$ \\
\hline S2A4 & $1.67 \pm 0.57$ & $2.67 \pm 0.57$ & $1.33 \pm 0.57$ \\
\hline S2T1 & $2.00 \pm 0.00$ & $3.67 \pm 0.57$ & $2.00 \pm 1.00$ \\
\hline S2T2 & $2.67 \pm 0.57$ & $1.00 \pm 0.00$ & $1.00 \pm 0.00$ \\
\hline S2T3 & $2.33 \pm 0.57$ & $3.00 \pm 1.00$ & $2.67 \pm 0.57$ \\
\hline S2T4 & $6.33 \pm 0.57 *$ & $6.67 \pm 0.57 *$ & $6.00 \pm 0.00 *$ \\
\hline S2T5 & $1.67 \pm 0.57$ & $2.67 \pm 0.57$ & $1.33 \pm 0.57$ \\
\hline S2T6 & $2.33 \pm 0.57$ & $1.67 \pm 0.57$ & $2.00 \pm 0.00$ \\
\hline S2B1 & $6.33 \pm 0.57 *$ & $2.67 \pm 1.15$ & 0 \\
\hline S2B2 & $3.00 \pm 0.00$ & $2.67 \pm 0.57$ & $3.33 \pm 0.57$ \\
\hline S2B3 & $2.00 \pm 1.00$ & $2.33 \pm 0.57$ & $2.67 \pm 0.57$ \\
\hline S2B4 & $3.33 \pm 0.57$ & $2.67 \pm 0.57$ & $3.67 \pm 1.15$ \\
\hline & Description: *strong inhibition against indicator bacteria \\
\hline
\end{tabular}


According to Table 2 the LAB isolates S1T1 have stronger inhibition against Gram-positive indicator (S. aureus ATCC 25923) than Gram-negative (S. typhi BPE 122.4 CCA and S. typhi NCTC 786), while strain S2B1 has the reverse effect. However, the S2T4 variant had strong inhibition with broad-spectrum against all the microbes investigated. Furthermore, some of the organisms produce antibacterial effects and prevent the growth of pathogenic bacteria, therefore protecting the host's defense against infections in the intestinal lumen [13]. The LAB is more profitable compared to other microorganisms, due to the antibacterial substances produced [25]. This characteristic is important for assessing the potential as a probiotic and producer of antimicrobial compounds [26]. Besides, tolerance to acidic $\mathrm{pH}$ and bile salts, with the ability to inhibit pathogenic bacteria are of benefit to human health.

\section{Identification of Lactic Acid Bacteria Isolates}

Furthermore, five LAB isolates tolerant of acidic $\mathrm{pH}$ and $1 \%$ bile salts, with strong inhibition against pathogenic bacteria were selected and identified using $50 \mathrm{CHL}$ Analytical Profile Index (API) (BioMérieux). These include S1B1, S2B1, S1T2, S2T4, and S1T1. Based on the Gram staining results in Figure 2, the Gram-positive characteristics of long rod cells were identified and arranged in groups or chains. These features are initial indications for the classification of isolates suspected to be Lactobacillus.

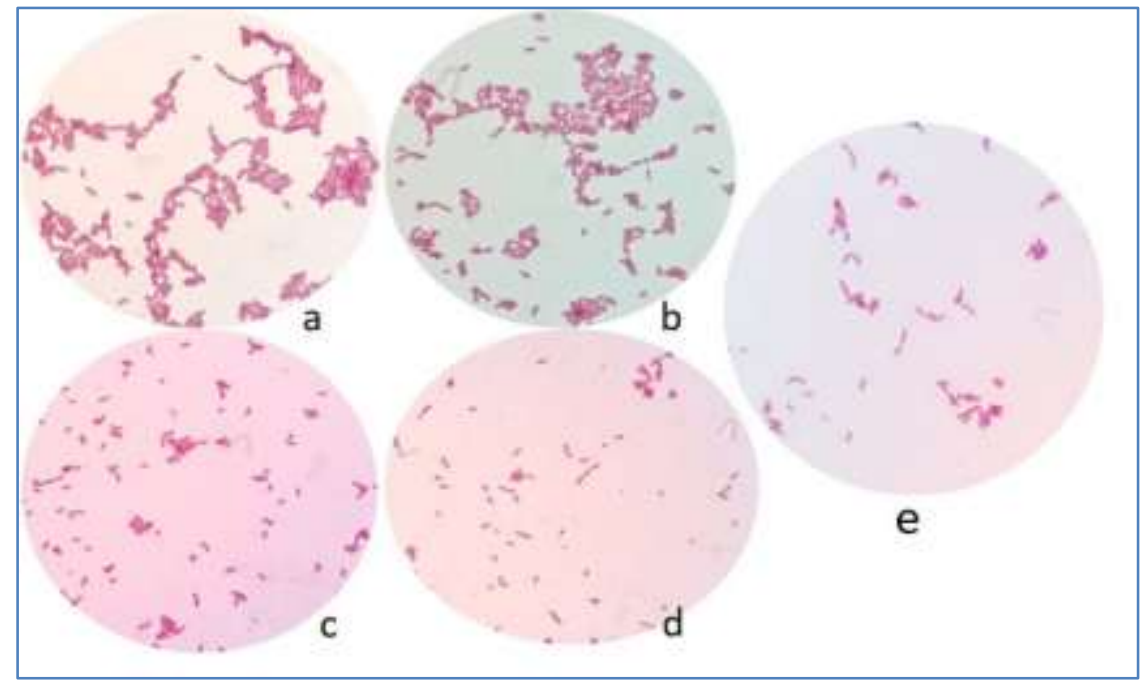

Fig-2: Cell morphology of lactic acid bacterial isolate from Papua red fruit, as potential probiotic candidate, based on Gram staining (a = strain S1B1; b = strain S2B1; c = strain S1T2; d = strain S2T4; e = strain S1T1)

Table 4 shows the results of the LAB isolates identification test performed using the API 50 CHL kit. Also, S1B1, S2B1, S1T2, S2T4, and S1T1 strains were able to ferment 23 carbon sources. These include L-arabinose, ribose, galactose, glucose, fructose, mannose, mannitol, sorbitol, methyl-D-monoxide,
$\mathrm{N}$-acetyl-glucosamine, amygdalin, arbutin, esculin, salicin, cellobiose, maltose, lactose, melibiose, sucrose, trehalose, melezitose, raffinose, $\beta$-gentiobiose, and D-turanose. Besides, data confirmation was performed using API web software, where $99.9 \%$ of the discovered isolates were similar to Lactobacillus plantarum 1. 
Charis Amarantini et al., Sch Acad J Biosci, September, 2020; 8(9): 301-308

Table-4: Identification of lactic acid bacterial isolates from Papuan red fruit selected as probiotic candidates using Analytical Profile Index (API) 50 CHL (BioMérieux)

\begin{tabular}{|c|c|c|c|c|c|c|}
\hline \multirow[t]{2}{*}{ No } & \multirow[t]{2}{*}{ Carbon sources } & \multicolumn{5}{|c|}{ Isolate } \\
\hline & & S1B1 & S1T2 & S2B1 & S2T4 & S1T1 \\
\hline 0 & Control & - & - & - & - & - \\
\hline 1 & Glycerol & - & - & - & - & - \\
\hline 2 & Erythritol & - & - & - & - & - \\
\hline 3 & D-Arabinose & - & - & - & - & - \\
\hline 4 & L-Arabinose & + & + & - & + & + \\
\hline 5 & Ribose & + & + & + & + & + \\
\hline 6 & D-Xylose & - & - & - & - & - \\
\hline 7 & L-Xylose & - & - & - & - & - \\
\hline 8 & Adonitol & - & - & - & - & - \\
\hline 9 & B-Methyl-D-Xyloxide & - & - & - & - & - \\
\hline 10 & Galactose & + & + & + & + & + \\
\hline 11 & Glucose & + & + & + & + & + \\
\hline 12 & Fructose & + & + & + & + & + \\
\hline 13 & Mannose & + & + & + & + & + \\
\hline 14 & Sorbose & - & - & - & - & - \\
\hline 15 & Rhamnose & - & - & - & - & - \\
\hline 16 & Dulcitol & - & - & - & - & - \\
\hline 17 & Inocitol & - & - & - & - & - \\
\hline 18 & Mannitol & + & + & + & + & + \\
\hline 19 & Sorbitol & + & + & + & + & + \\
\hline 20 & Methyl-D-Mannoxide & + & + & + & + & + \\
\hline 21 & Methyl-D-Glucoxide & - & - & - & - & - \\
\hline 22 & N-Acetyl-Glucosamine & + & + & + & + & + \\
\hline 23 & Amygdalin & + & + & + & + & + \\
\hline 24 & Arbutin & + & + & + & + & + \\
\hline 25 & Esculin & + & + & + & + & + \\
\hline 26 & Salicin & + & + & + & + & + \\
\hline 27 & Cellobiose & + & + & + & + & + \\
\hline 28 & Maltose & + & + & + & + & + \\
\hline 29 & Lactose & + & + & + & + & + \\
\hline 30 & Melibiose & + & + & + & + & + \\
\hline 31 & Sucrose & + & + & + & + & + \\
\hline 32 & Trehalose & + & + & + & + & + \\
\hline 33 & Inulin & - & - & - & - & - \\
\hline 34 & Melezitose & + & + & + & + & + \\
\hline 35 & Raffinose & + & + & + & + & + \\
\hline 36 & Starch & - & - & - & - & - \\
\hline 37 & Glycogen & - & - & - & - & - \\
\hline 38 & Xylitol & - & - & - & - & - \\
\hline 39 & $\beta$-Gentiobiose & + & + & + & + & + \\
\hline 40 & D-Turanose & + & + & + & + & + \\
\hline 41 & D-Lyxose & - & - & - & - & - \\
\hline 42 & D-Tagatose & - & - & - & - & - \\
\hline 43 & D-Fucose & - & - & - & - & - \\
\hline 44 & L-Fucose & - & - & - & - & - \\
\hline 45 & D-Arabitol & - & - & - & - & - \\
\hline 46 & L-Arabitol & - & - & - & - & - \\
\hline 47 & Gluconat & - & - & - & - & - \\
\hline 48 & 2-Keto-Gluconat & - & - & - & - & - \\
\hline 49 & 5-Keto-Gluconat & - & - & - & - & - \\
\hline & Identification Results & L. plantarum 1 & L. plantarum 1 & L. plantarum 1 & L. plantarum 1 & L. plantarum 1 \\
\hline & Similarity Index & $99,9 \%$ & $99,9 \%$ & $99,9 \%$ & $99,9 \%$ & $99,9 \%$ \\
\hline
\end{tabular}


The LAB isolate identification proves $L$. plantarum to be naturally present in plant materials and also its fermentation products [27, 28]. Furthermore, the prebiotic inulin content in red fruits is also considered a factor supporting LAB growth. Murtiningrum et al. [10] conducted an in vitro evaluation, and the results showed the ability for inulin present in the pedicel extract to supports Lactobacillus casei development.

The Lactobacillus plantarum strain S2T4 grows under acidic $\mathrm{pH}$ conditions and are also tolerant to bile salts. These microorganisms have strong inhibitory power with varying spectra against $S$. aureus ATCC 25923, S. typhi BPE 122.4 CCA, and S. typhi NCTC 786 indicator bacteria. Furthermore, the strain S1T1 had stronger inhibition against Gram-positive species $(S$. aureus ATCC 259230) than the Gram-negative. However, the inverse was reported for the S2B1 strain and was estimated to significantly inhibit only S. typhi BPE 122.4 CCA, while the other two strains (S1B1, S1T2) had a moderate effect, and similar results have been reported in other studies. Among the Lactobacillus members, L. plantarum species are known as functional probiotics and have been identified in many fermented, probiotic, and naturally processed foods [29]. Hu et al. [19] isolated three species of antimicrobial producing $L$. plantarum (strains P1; M7, and S11), with the capacity to inhibit some indicator bacteria, including $S$. aureus ATCC 12600, E. coli ATCC 35128, and Salmonella ASI.1174. A research conducted by Gutiérrez-Cortés et al. [2] recognized the presence of four Lactobacillus ( $L$. casei, L. brevis, L. paracasei, and L. plantarum) and Pediococcus acidilactici species with antagonistic properties against $E$. coli ATCC 25922, S. aureus ATCC 25923, and Listeria monocytogenes ATCC 7644. The five isolates of L. plantarum (S1B1, S2B1, S1T2, S2T4, and S1T1) are essential for further research on the intrinsic potentials as probiotic candidates for use as antibacterial and preservative agents.

\section{CONCLUSIONS}

The lactic acid bacteria strains S1B1, S2B1, S1T2, S2T4, and S1T1 isolated from Papuan red fruit were identified as Lactobacillus plantarum and determined to survive at $\mathrm{pH} 2$ and bile salt $1 \%$. These isolates have the potential for further development as probiotic candidates. Specifically, the S2T4 strain has a strong inhibitory capacity against $S$. aureus ATCC 25923, S. typhi BPE 122.4 CCA, and S. typhi NCTC 786, while S2B1 and S1T1 significantly hinder the growth of Salmonella typhi BPE 122.4 CCA and S. aureus ATCC 25923, respectively. Besides, three isolates, including S2T4, S2B1, and S1T1 also have the potential for further advancement as biopreservatives.

\section{ACKNOWLEDGEMENTS}

Our gratitude goes to the Faculty of Biotechnology Universitas Kristen Duta Wacana which is funding this research in 2020 with a project number 118/D.01/Bio/2020.

\section{REFERENCES}

1. Yang E, Fan L, Jiang Y, Doucette C, Fillmore S. Antimicrobial activity of bacteriocin-producing lactic acid bacteria isolated from cheeses and yogurts. AMB Express. 2012; 2: 48-60.

2. Gutiérrez CC, Suárez H, Buitrago G, Moreno $\mathrm{CD}$. Isolation and evaluation of the antagonist activity of lactic acid bacteria in raw cow milk. Agronomía Colombiana. 2017; 35(3): 357-364.

3. Allen SJ, Martinez EG, Gregorio GV, Dans LF. Probiotics for treating acute infectious diarrhoea. John Wiley \& Sons Ltd. UK; 2011.

4. Mokoena, MP. Lactic acid bacteria and their bacteriocins: classification, biosynthesis and application against uropathogens: a mini-review. Molecules. 2017; 22(8): 1-13.

5. [Tham CSC, Peh KK, Bhat R, Liong MT. Probiotic properties of Bifidobacteria and Lactobacilli isolated from local dairy products. Annals of Microbiology. 2012; 62(3):1079-1087.

6. Kandler, O. Current taxonomy of Lactobacilli. Industrial Microbiology. 1984; 25: 9-123.

7. Saguibo JD, Mercado MA, Maldia ST, Jimeno BT, Perez MTM, Calapardo MR, Elegado FB. Identification and characterization of lactic acid bacteria isolated from some medicinal and/or edible Philippine plants. Food Research. 2019; 3(6): 698-712.

8. Dinoto A, Rosyidah A, Susilo ARPS, Julistiono H. Isolation, identification and antimicrobial activities of lactic acid bacteria from fruits of wild plants in Tambrauw Forest, West Papua, Indonesia. Biodiversitas. 2020; 21(7): 3391-3397.

9. Rohman A, Man YBC, Riyanto S. Authentication analysis of red fruit (Pandanus conoideus Lam.) oil using FTIR spectroscopy in combination with chemometrics. Phytochemical Analysis. 2011; 22(5): 462-467.

10. Murtiningrum, Suryadarma P, Suryani A, Manguwidjaja D. Identification of inulin profile from red fruit (Pandanus conoideus) pedicel extract using LC-MS and it's in vitro prebiotic activity test. International Journal Advanced Research. 7(11): 344-351.

11. Sneath PHA, Mair NS, Sharpe ME, Holt JG. Bergey's manual of systematic bacteriology, 
vol. 2. in Garrity, GM (Ed.), Williams JG, Wilkins (Co.). Baltimore Md; 2009.

12. Pramono H, Suciati P, Andriyono S. Isolation of lactic acid bacteria that produce protease and bacteriocin-like substance from mud crab (Scylla sp.) Digestive Tract. Ilmu Kelautan. 2015; 20(1): 33-7.

13. Shi $T$, Nishiyama $K$, Nakamata $K$, Aryantini NPD, Mikumo D, Oda Y, Yamamoto Y, Mukai T, Sujaya IN, Urashima T, Fukuda K. Isolation of potential probiotic Lactobacillus rhamnosus strains from traditional fermented mare milk produced in Sumbawa Island of Indonesia. Bioscience, Biotechnology, and Biochemistry. 2012; 76: 1897-1903.

14. Baloch MN, Siddiqi R, Zehra S, Zia M. Characterization of lactocin 1c-09 produced by Lactobacillus acidophilus. International Journal of Current Research. 2015; 7: 13471-13476.

15. Amarantini C, Sembiring L, Kushadiwijaya H, Asmara W. Identification and characterization of Salmonella typhi isolates from South-west Sumba District, East Nusa Tenggara based on 16S rRNA gene sequences. Biodiversitas. 2011; 12: 1-6.

16. Klayraung S, Okonogi S. Antibacterial and Antioxidant Activities of Acid and Bile Resistant Strains of Lactobacillus fermentum Isolated from Miang. Brazilian Journal of Microbiology. 2009; 40(4): 757-766.

17. Fernandez B, Le Lay C, Jean J, Fliss I. Growth, acid production and bacteriocin production by probiotic candidates under simulated colonic conditions. Journal of Applied Microbiology. 2013; 114: 877-885.

18. Pan X, Chen T, Wu H, Tang, Zhao Z. The acid, bile tolerance and antimicrobial property of Lactobacillus acidophilus NIT. Food Control. 2009; 20: 598-602.

19. $\mathrm{Hu} \mathrm{CH}$, Ren QL, Zhou Y, Ye CB. Characterization of antimicrobial activity of three Lactobacillus plantarum strains isolated from Chinese traditional dairy food. Food Science \& Nutrition. 2019; 7(6): 199-2005.

20. Martinez RC, Wachsman M, Torres NI, Leblanc JG, Todorov SD, Franco BD.
Biochemical, antimicrobial and molecular characterization of a noncytotoxic bacteriocin produced by Lactobacillus plantarum ST71KS. Food Microbiol. 2013; 34(2):376-381.

21. Dewi SS, Herlisa A. Viabilitas bakteri asam laktat asal ASI terhadap $\mathrm{pH}$ asam lambung dan garam empedu. Seminar Penelitian LPPM UNIMUS ISBN: 978-602-18809-0-6. 2012; 97-102.

22. Lahtinen S, Ouwehand AC, Salminen S, Wright AV. Lactic acid bacteria: microbiological and functional aspects $4^{\text {th }} \mathrm{Ed}$. 1:2-14. CRC Press: Taylor and Francis Group; 2012.

23. Makinen K, Berger B, Bel-Rhlid R, Ananta E. Science and technology for the mastership of probiotic applications in food products. Journal of Biotechnology. 2012; 162(4): 356-365.

24. Qian Y, Long X, Pan Y, Li G, Zhao X. Isolation and identification of lactic acid bacteria (Lactobacillus plantarum YS2) from yak yogurt and its probiotic properties. Biomedical Research. 2018; 29(4): 815-820.

25. [25] Nigam A, Kumar A, Madhusudan HV, Bhola N. In-vitro screening of antibacterial activity of lactic acid bacteria against common enteric pathogens. Journal of Biomedical Sciences. 2012; 1(4): 2.

26. Amarantini C, Satwika D, Budiarso TY, Yunita ER, Laheba EA. Screening of antimicrobial-producing lactic acid bacteria isolated from traditional fish fermentation against pathogenic bacteria. Journal of Physics. Conference Series 1397 2019; 012045.

27. Todorov SD, Franco B. Lactobacillus plantarum: characterization of the species and application in food production. Food Review International. 2010; 26(3): 205-229.

28. Khemariya P, Singh S, Jaiswal N, Chaurasia SNS. Isolation and identification of Lactobacillus plantarum from vegetable samples. Food Biotechnology. 2016; 30(1): 49-62.

29. Guidone A, Zotta T, Ross RP, Stanton C, Rea MC, Parente E, Ricciardi A. Functional properties of Lactobacillus plantarum strains: a multivariate screening study. Food Science and Technology. 2014, 56(1): 69-76. 